\title{
Research and Implementation of Supply Chain Financing Service Based on Core Enterprises
}

\author{
Xiuwen Gan \\ College of Economics and Management, Nanjing Institute of Technology, Nanjing, 211167, China
}

Keywords: Core enterprises, Supply chain, Financing service

\begin{abstract}
. supply chain financing service gradually develops under the promotion of small and medium enterprise financing. As a novel financing mode in current society, it can not just effectively relieve financing plight for small and medium enterprises, but also practically improve cooperation force of enterprises in the whole supply chain. This paper starts from core enterprises, and analyzes the function of core enterprises in supply chain financing service. Then, this paper takes supply chain financing practice of China Telecom Group Sichuan Branch Office for example and carries out comprehensive and careful analysis of supply chain financing service based on core enterprises, in the hope of proving certain reference for actual operation of supply chain financing.
\end{abstract}

\section{Introduction}

In China, under the situation of monetary stringency in recent years, it is difficult for small enterprises to gain loans in time. This has been a well-known problem in the whole society. However, it is necessary to notice that this problem is not generated under China's general environment. Worldwide, since small and medium enterprises lack the fixed assets used for mortgage, banks consider their credit risk is large; bank evaluation cost is too high; they lack credit rating to some extent during risk evaluation. Thus, it is hard for banks to open low-cost credit loan. In a sense, capital has gradually become a bottleneck restricting development of small and medium enterprises. Thus, financial research institutions conform to market development trend and gradually explore supply chain financing service. It not just helps small and medium enterprises to break such capital limit bottleneck, but also can provide new direction for bank development and promote development of the whole market economy.

\section{Functions of core enterprises in supply chain financing service}

In the process of financing activities, core enterprises have been in the central position of supply chain. They relieve upstream and downstream financing risks and provide certain risk guarantee for financing activities of upstream and downstream enterprises. Firstly, core enterprises serve as fundamental guarantee for smooth implementation of supply chain activities. They own strong enterprise prestige and overall strength, can play certain role in enterprise financing in the supply chain, reduce enterprise financing cost on the whole and drive smooth implementation of each link of supply chain financing activities so as to further improve market competitiveness of supply chain. In this process, just because core enterprises own strong enterprise prestige and economic strength, fund providers in supply chain financing links carefully consider financing of small and medium enterprises so as to help upstream and downstream enterprises to smoothly carry out relevant business and achieve win-win of multiple enterprises in the supply chain. Secondly, core enterprises can alleviate non-equivalence degree between banks and small \& medium enterprises which want to gain financing. Core enterprises as the bond connecting banks and small \& medium enterprises are the key of supply chain financing activities. During analyzing small and medium enterprises for banks, core enterprises should fully know each enterprise in the supply chain and select the most suitable financing services for banks, small and medium enterprises. In this way, core enterprises as guarantors of financing activities give full play to their leading role for financing activities. They simplify traditional and relatively complex bank loan, and also to some extent solve the difficulty in 
checking and supervising assets of the borrowing unit in loan proving process. Thirdly, core enterprises as guarantors of financing activities can directly participate in all financing businesses in supply chain while sharing financing risks so as to drive fund flow of the whole industry chain, boost fund utilization efficiency and make enterprises gain long-term benefits. In some supply chain financing activities, core enterprises will also utilize their advantages to provide more fund occupation time for downstream enterprises through relevant financing ways and gain certain income in time.

\section{Supply chain financing practice of China Telecom Group Sichuan Branch Office}

Scientific theory can gradually evolve to social productive force through technicalization and industrialization changes. Technological treatment of scientific theory is to apply scientific theory in specific practice process with practicability as development goal so as to further shorten the distance between scientific theory and actual social productive forces. Technological industrialization aims to achieve profit and apply relevant achievements in industrial practice. For this, China Telecom Group Sichuan Branch Office makes corresponding innovation and demonstration in supply chain financing.

Overall structure framework of core enterprises participating in supply chain financing

China Telecom Group Sichuan Branch Office (herein after referred to as "Sichuan Branch Office”) is a leading enterprise in Sichuan Telecom subject which provides comprehensive information service. Original value of its fixed assets is 19.5 billion Yuan. Currently, it owns employees about 17000 , and employees' average age is 35.

Telecom enterprises construct corresponding industrial value chain with telecom operation as the core. It is an industrial supply chain consisting of network equipment supply enterprises, content service supply enterprises, system integration enterprises, terminal equipment manufacturing enterprise, professional software development enterprises, commodity distribution enterprises and final users etc. It can create stronger enterprise synergistic effect than original single enterprises. In this supply chain, it is hard for many agents, small and medium enterprises to gain loans from banks. In such case, Sichuan Branch Office as a strong core enterprise can utilize its enterprise prestige and status breaks traditional financial limitation of upstream and downstream enterprises in the supply chain in traditional financing and help upstream product supply enterprises and downstream product distribution enterprises gain banks' financing services so as to inject new power for benign development of the whole industrial chain.

\section{Order financing as breakthrough of supply chain financing service}

Sichuan Branch Office firstly launches "supply chain financing platform” according to overall features of product supply enterprises in telecom industry and provides characteristic order financing business. Construction of supply chain financing platform mainly aims to solve corresponding fund demand of Sichuan Branch Office during holding purchase order of Sichuan Branch Office. Through communication with banks, supply chain financing platform provides certain financing services for enterprises holding orders. In this way, product supply enterprises can obtain certain financing by virtue of product purchase order. Besides, such financing has great advantages compared with traditional trade financing. Funds from bank financing can intervene in advance, which can avoid fund supply-demand deviation due to delay of invoice issuance and really fill up financing gap. Meanwhile, this platform mainly pays attention to rational verification of order authenticity and accuracy of payment account number during product investigation and practically implements guarantee measures of product supply enterprises. In this way, examination and approval time of supply chain financing service shortens by a large margin. Examination and approval timeliness strengthens significantly. This saves precious time for enterprise activities. Thus, Sichuan Branch Office as a core affiliated enterprise enters the supply chain. This ensures order authenticity and reliability and also provides great possibility for completely saving transaction records to some extent. 
Furthermore, according to survey of China Construction Bank about development status of supply chain financing service in each industry, only very few large core enterprises in China provide corresponding financing guarantee services for product supply enterprises. And the service contents and financing support system become increasingly perfect. They just purely provide simple guarantee or information support for financing activities, and do not really form sound supply chain financing service synergy and IT support system of financing service. However, Sichuan Branch Office makes innovation in practice. It not just drives efficient integration of upstream and downstream enterprises in the supply chain, but also makes relevant financial services in supply chain activities intervene in overall activity system of supply chain, shares risks of small and medium enterprise financing and provides new development thought for supply chain financing service in the same industry.

\section{Functions and structure of supply chain financing platform}

Supply chain financing of Sichuan Branch office mainly includes Sichuan Branch office, banks and product supply enterprises:

Product supply enterprises mainly provide query, financing service consultation, transmission and material reception for related loan application, examination and approval in supply chain financing.

Banks mainly provide secondary examination and verification of qualification, contract and fund checking of supply enterprises for supply chain financing and also provide reception, examination, approval and late reply of loan application. Besides, bank port in supply chain can support multiple banks to be online at the same time. Product supply enterprises can issue application to corresponding banks according to actual needs during selecting loan application. In the future, product supply enterprises can integrate banks' credit extension system and factoring system in line with practical development status and gradually achieve all-round terminal-to-terminal financial financing service.

Sichuan Branch Office mainly provides financing application, query and checking for financing activities in the supply chain.

Supply chain financing platform in the supply chain was established in 2009. It just took 5 months from completion to implementation. It obtains good effects in later development. The $21^{\text {st }}$ century is the period of rapid market competition. Market competition contents have gradually developed to competitions among industry supply chain from pure corporate strength competitions. Construction of supply chain financing platform by Sichuan Branch Office not just consolidates long-term cooperation relationship between the company and banks and among product supply enterprises, but also plays a great role in promoting competitions of telecom industry.

\section{Solid and firm information support system}

Supply chain financing platform of Sichuan Branch Office is based on eSRM system. Qualification information of all product supply enterprises needs to be registered in eSRM system. After passing examination and verification of qualification, product supply enterprises can officially enter the supply chain and become an important part of the supply chain as product supplier of Sichuan Branch office. Meanwhile, enterprises should update enterprise qualification information in time after the period of qualification validity expires and applies for secondary examination and approval so as to promote supply chain financing platform to achieve standard management. This can guarantee validity and completeness of product supply enterprises, and realize unification and clearness of management window interface. This is beneficial to dynamic management of a series of problems, such as admission and certification of product supply enterprises.

For purchase demand, results, clear contracts and orders published by Sichuan Branch Office, each small branch office in the whole province should uniformly publish the information in eSRM system at the same time and inform product supply enterprises to inquire relevant information via SMS or email. After the contract is formally performed, product supply enterprises also should propose payment application through payment interface in eSRM system and inquire detailed payment state regularly so as to really achieve closed-loop management of transaction process of the whole supply chain and drive standard and efficient development of business of purchase enterprises.

Through implementing the above management problems, eSRM system can gradually develop to complete information set which integrates product supply enterprise qualification, contract, goods delivery and payment. In this process, stable client group is collected. This, a favorable foundation is 
laid for developing financing business and setting up solid supply chain financing platform. This ensures stable upstream and downstream financing system in supply chain activity of Sichuan Branch office.

In terms of business operation process of financing activities, eSRM system officially imbeds financing service in a key link of supply chain financing service of Sichuan Branch office, achieves seamless integration of telecom terminal, product supply enterprise terminal and bank terminal and gradually constructs closed-loop business process of a relatively complete supply chain.

\section{Risk control of Sichuan telecom supply chain financing service}

In specific operation process of supply chain financing service, for each party participating in financing activities, certain risks will certainly exist. Core enterprises need to adopt certain measures for scientific control and control risks to the lowest range. In order to really reduce risks in enterprise order financing, two aspects can be considered: firstly, it is required to establish sound cooperative system for product supply enterprises and accumulate historical transaction data of product supply enterprises. The major risk of enterprise order financing lies in authenticity and reliability of order contract and self-compensation features. Banks pay more attention to transaction evaluation. Thus, accumulation of historical transaction data of product supply enterprises is of great importance. As transaction times increase continuously, credit line of product supply enterprises will also rise. Secondly, it is required to enhance construction of evaluation system and ensure close relationship with product supply enterprises. Construction of product supply enterprise evaluation system can promote perfection of credit system and then strengthen admission and quit standard construction of product supply enterprises. For core enterprises, the key to controlling order financing risk lies in ensuring credit of each enterprise, while enterprise credit is limited by cooperative relationship of upstream and downstream enterprise in the supply chain. So, it is required to attach importance to construction of accumulative credit system and guarantee integrity of evaluation system so as to monitor financing risks in the supply chain.

\section{Conclusions}

Seeing from current financing market development in China, the proposal of supply chain financing is a great innovation of society. It makes huge contributions to relieve financing plight of Chinese small ad medium enterprises in the development process and also provides a new direction for financing development in each industry. It is an inexorable trend of future financing development.

\section{Acknowledgments}

This is a part of philosophy and social science fund program of colleges in Jiangsu: study in financing optimization and operation management coordination decision in capital constraint supply chain (project No.: 2013SJD630024)

\section{References}

[1] Zhang Jingfeng, Wang Ping, Study on supply chain financing and its management framework. Journal of Beijing Technology and Business University (Social Sciences), 2013,28(3)

[2] Yao Jing, Study on supply chain financing risk of small and medium enterprises and its prevention. Chinese Times (mid-month periodical), 2013(8).

[3] Huang Ping, Ren Shiyang, Problems and countermeasures of core enterprises participating in supply chain financing. Journal of Tongling University, 2014(1)

[4] Shen Lianxiang, Discussion on how to effectively utilize supply chain financing service by commerce and trade enterprises - perspective based on credit business of commercial banks. China Business \& Trade, 2014(15) 
[5] Bao Jinghai, Analysis of joint guarantee financing mode of core enterprises, small and medium enterprises. Financial Theory \& Practice, 2013(7) 